\title{
PENGARUH SUHU DAN WAKTU AKTIVASI TERHADAP KAPASITAS ADSORPSI KOKAS MINYAK BUMI
}

\author{
Rayandra Asyhar dan Nofrizal Jon \\ Laboratorium Kimia UP-MIPA Universitas Jambi \\ Jl. Jambi-Ma. Bulian KM 15 Mendalo Darat Jambi 36361
}

\begin{abstract}
The effect of activation temperature and duration on the activity of petroleum coke has been investigated. A mixture of green coke and $\mathrm{KOH}(1: 1)$ was heated in an oven furnace at $450^{\circ} \mathrm{C}$ for 1 $\mathrm{h}$, then continued to activation process at $450-900^{\circ} \mathrm{C}$ for $1-3 \mathrm{~h}$. The product mixture was immersed in a solution of $10 \% \mathrm{H}_{2} \mathrm{SO}_{4}$ before being washed with deionized water to neutral $\mathrm{pH}$. After being dried, activated cokes were tested with a solution of phenol, 4-nitrophenol, 2,4-dinitrophenol or methylen blue. Experimental data showed that the activity of coke imcreased with temperature and time. The effective condition of the activation process is at temperatures higher than $750{ }^{\circ} \mathrm{C}$ and activation time of longer than $1,5 \mathrm{~h}$. Adsorptive behavior of phenolics dan metylene blue onto activated coke agreed with Langmuir rather than with Freundlich isotherm.
\end{abstract}

Keywords: temperature effect, activation time, petroleum coke, adsorption capacity, phenolics, methylen blue.

\section{DAFTAR PUSTAKA}

1. Asyhar, R., 2002, Preparation of Active Sorbent from Petroleum Coke and Its Application for Phenol and 4-Nitrophenol Reduction from Aqueuos Solution, Fresenius Environ. Bull., 3 (1): 149-155.

2. Asyhar, R., 2002, Equlibrium Studies of Activated Petroleum Coke Towards Phenol and 4-Nitrophenol, Fresenius Environ. Bull., 6 (1): 272-279.

3. Asyhar, R., 2002, Activation of Petroleum Coke and Its Application for the Removal of Phenols and Dyes from Waste Water, $S$ 3 Dissertation, Tecnical University Braunschweig, Germany.

4. Asyhar, R., Wichmann, H., Bahadir, M., 2002, Untersuchungen zur Entfernung organischer Schadstoffe vom Abwaessers mittels konditioniertem Petrolkoks, Umwelt Jahrestagung, 18-20 Oktober 2002 in Braunschweig, Germany.

5. Anonim, 2006, Warta Pertamina Edisi 7/Thn XLI/ Juli 2006, Internet: www.wartapertamina.ac.id diakses 10 September 2006.
6. Lee, J. M., Baker, J. J., Murray, D., Lierena, R., and Rolle, J. G., 1998, Quality analysis of petroleum coke and coals for export specifications required in use of specialty products and utility fuels, American Chemical Society, Division of Fuel Chemistry, 42 (3): 844-853.

7. Asyhar, R., 2000, Analysis Kandungan Logam dalam Kokas Minyak Bumi dan Potensinya Terhadap Pencemaran Lingkungan, Wahana Komunikasi Sains Indonesia, 3 (3): 150-155.

8. Asyhar, R., 2004, Analisis Kandungan Senyawa Hidrokarbon Polisiklik Aromatis pada Kokas Minyak Bumi, Jurnal Kimia Universitas Jambi, 1 (1): 18-24.

9. Asyhar, R., Jon, N., dan Idiasari, R., 2004, Adsorpsi Metilen Biru pada Kokas dan Batubara, Laporan Penelitian, Universitas Jambi.

10. Jagtoyen, M., Thwaites, M., Stencel, J., Mcnaney, B., and Derbhisyre, F., 1992, Adsorbent carbon synthesis from coals by phosphoric acid activation, Carbon, 30 (7): 1089-1096.

11. Dipanfilo, R., and Egiebor, N. O., 1996, Activated carbon production from 
synthetic crude coke, Fuel Processing Technology, 46: 157-169.

12. Shawwa, A. R., Smith, D. W., and Sego, D. C., 2001, Color and chlorinated organics removal from pulp mills wastewater using activated petroleum coke, Wat. Res., 35 (3): 745-749.

13. Asyhar, R., dan Jon, N., 2006, Pemanfaatan Kokas Minyak Bumi Sebagai Adsorben dalam Proses Pengolahan Air Limbah Batik, Laporan Penelitian Hibah Bersaing DP2M, Universitas Jambi.
14. Teng, H., and Shieh, C-T., 1999, LiquidPhase Adsorption of Phenol by Activated Carbons Prepared from Bituminous Coals with Different Oxygen Contents, J. Chem. Technol. Biotechnol., 74: 123-130.

15. Otowa, T., Nojima, Y., and Miyazaki, T., 1997, Development of KOH activated high surface area carbon and its application to drinking water purification, Carbon, 35 (9): 1315-1319. 